\title{
GENEOLOGI TAFSIR SUFISTIK DALAM KHAZANAH PENAFSIRAN AL-QUR'AN
}

\author{
Muhamad Zaenal Muttaqin \\ Program Studi Ilmu al-Qur'an dan Tafsir \\ IAIN Syekh Nurjati Cirebon \\ zaenalmuttaqin@syekhnurjati.ac.id
}

\begin{abstract}
Abstrak
Keberadaan tafsir sufistik sangat menarik untuk dikaji, tanggapan terhadap corak penafsiran ini pun sangat beragam, mulai dari yang mendiskreditkan sampai mengapresiasinya. Eksistensi corak penafsiran sufistik dengan kekhasannya sangat mewarnai khazanah penafsiran al-Qur'an. Sejatinya, corak tafsir ini lebih didasarkan pada pemikiran, perenungan dan pengalaman spiritual dari para sufi. Pada perjalanannya tafsir ini kemudian terbagi menjadi dua, yaitu tafsír Süfí al-Nazări dan Tafsì Süfí al-Ishärí. Tulisan ini akan menelusuri tentang bagaimana diskursus penafsiran sufistik serta sejarah pertumbuhan dan pekembangannya dari zaman Nabi Saw sampai sekarang.
\end{abstract}

\section{Keywords: Sufisticc Interpretation Geneology, Quranic} Interpretation.

\section{Pendahuluan}

Kajian terhadap al-Qur'an selalu berkembang secara dinamis seiring akselerasi perkembangan kondisi sosial-budaya dan peradaban dunia. Hal ini dibuktikan dengan munculnya karya-karya tafsir, baik dari yang klasik hingga kontemporer, dengan berbagai corak, metode, dan pendekatan. ${ }^{1}$ Perkembangan zaman dan kemajuan ilmu pengetahuan juga menjadai faktor pendorong para mufassir dalam membuka tabir al-Qur'an, sehingga membuat corak penafsiran lebih bervariasi. ${ }^{2}$

\footnotetext{
${ }^{1}$ Abdul Mustaqim, Epistemologi Tafsir Kontemporer (Yogyakarta: LKIS, 2012), 1.

2 Muhammad Husayn al-Dhahabi membagi sejarah penafsiran al-Qur'an ke dalam tiga fase, yaitu: pertama, adalah fase perkembangan tafsir pada masa Nabi dan para sahabat; kedua, yaitu fase perkembangan tafsir pada masa tabi'in; ketiga, fase perkembangan tafsir pada masa penyusunan dan pembukuan yang dimulai dari zaman 'Abbasiyah sampai zaman kontemporer. Lihat Muhammad Husayn al-Dhahabi, Al-Tafsir wa al-Mufassirün (Kairo: Maktabah Wahbah, 2000), Jilid I, 32-342.
} 
Muhammad Quraish Shihab ${ }^{3}$ menjelaskan bahwa setidaknya corak penafsiran yang dikenal selama ini antara lain: corak sastra bahasa (al-tafsir al-lughāwì al-baläghî), ${ }^{4}$ filsafat dan teologi (al-tafsir al-falsāfí) ${ }^{5}$ penafsiran ilmiah (al-tafsir al- 'ilmî), ${ }^{6}$ fiqih atau hukum (al-tafsir al-fiqhï/ al-tafsir alayāt al-ahkkām), ${ }^{7}$ tasawuf (al-tafsìir al-șüfí) ${ }^{8}$ dan sastra kebudayaan kemasyarakatan (al-tafsìir al-adab al-ijtimā' $\overline{1}){ }^{9}$

Keberadaan tafsir sufistik menjadi fenomena yang menarik untuk dikaji, beragam penilaian terhadap corak penafsiran ini bermunculan. Sebagian kalangan menyangsikan otoritas kaum sufi dalam menafsirkan alQur'an, tetapi tidak sedikit pula yang membela. Kalangan yang tidak setuju dengan tafsir sufistik menganggap bahwa metode karena mirip dengan

Lihat juga Mannā' al-Qaț̣ān, Mabāhith fí 'Ulūm al-Qur'ān (Kairo: Maktabah Wahbah, 2000), 326333.

${ }^{3}$ Muhammad Quraish Shihab, Membumikan al-Qur'an: Fungsi dan Peran Wahyu dalam Masyarakat (Bandung: Mizan, 1994), 72-73.

${ }^{4}$ Corak ini timbul akibat kelemahan-kelemahan orang Arab sendiri dalam bidang sastra, sehingga dirasa perlu untuk menjelaskan keistimewaan dan kedalaman kandungan al-Qur'an di bidang ini. Lihat Abuddin Nata, Metodologi Studi Islam (Jakarta: Rajawali Pers, 2012), 216.

${ }^{5}$ Corak tafsir ini muncul sebagai akibat dari kemajuan dalam bidang ilmu pengetahuan dan kebudayaan, serta adanya gerakan penerjemahan buku-buku asing ke dalam bahasa Arab pada masa khalifah Abbasiyah. Buku-buku yang diterjemahkan kebanyakan buku-buku filsafat, seperti karya Aristoteles dan Plato. Lihat Abuddin Nata, Metodologi Studi Islam, 216.

${ }^{6}$ Corak ini diakibatkan oleh kemajuan ilmu pengetahuan serta usaha para mufassir untuk memehami ayat-ayat al-Qur'an yang sejalan dengan perkembangan ilmu. Abuddin Nata, Metodologi Studi Islam, 216.

${ }^{7}$ Kemunculan corak ini lebih diakibatkan semakin berkembangnya kajian ilmu Fiqih, dan terbentuknya mazhab-mazhab fiqih, yang dimana setiap golongan berusaha untuk membuktikan kebenaran berdasarkan penafsiran-penafsiran mereka terhadap ayat-ayat hukum, contoh tafsir ini adalah Ahkām al-Qur'ān karya al-Jașāṣ (Ḥanāfi); Al-Jām'i' li ahkām al-Qur'ān karya al-Qurtubī (Maliki); Kanz al-'Irfän fỉ Fiqh al-Qur'àn karya Miqdād al-Saiwarì (Syi'ah Ithna 'ash'ariyah).

${ }^{8}$ Adapun corak tafsir ini lebih didasarkan oleh pemikiran sufi, tafsir ini terbagi menjadi dua bagian: tafsìr Süfí al-Nazāài, yaitu tafsir yang didasarkan atas perenungan pikiran penulis tafsir tersebut seperti renungan filsafat. Menurut al-Dhahabi, tafsir ini tertolak. Lihat Muhammad Ḥusayn al-Dhahabi, al-Tafsìr wa al-Mufassirūn, Jilid II, 346. Bagian kedua dari jenis tafsir sufi adalah Tafsìr Süfí al-Ishàrī, yaitu tafsir yang didasarkan atas pengalaman pribadi (kashāf), seperti Tafsìr al-Qur'ān al- 'Adhìm karya al-Tustarì; Haqā'iq al-Tafsìr karya al-Sulamì dan Arāis al-Bayān fì Haqāiq al-Qur'ān karya al-Shirāzì. Menurut al-Dhahabi Tafsìr süfí ishāri ini dapat diterima dengan beberapa syarat: 1) terdapat dalil syar'i yang menguatkan. 2) tidak bertentangan dengan syariat. 3) tidak menafikan makna zahir teks. Jika tidak memenuhi syarat-syarat tersebut maka akan tertolak. Muhammad Ḥusayn al-Dhahabi, Al-Tafsìr wa al-Mufassirūun, Jilid II, 377.

${ }^{9}$ Corak tafsir ini menjelaskan petunjuk ayat-ayat al-Qur'an yang berkaitan langsung dengan kehidupan masyarakat, serta sebagai usaha untuk menanggulangi permasalahan yang terjadi berdasarkan petunjuk ayat. Dengan kata lain, penafsiran corak ini tidak disandarkan pada pendapat fuqaha' 'tertentu dan tokoh-tokoh aliran keagamaan dan pemikiran yang telah berlalu, dan tidak juga terbatasi oleh sebab nuzul yang dipahami secara harfiyyah, melainkan didasarkan pada pertimbangan akal, kondisi sosial dan tuntutan jamannya. Lihat Bakri Syaikh Amin, Al-Ta'bïr al-Fannī fí al-Qur'ān (Kairo: Dār al-Shurūq, 1980), 134. 
metode ta'wīl yang dilakukan kalangan Syi'ah Bätiniyyah yang tidak berangkat dari pemaknaan secara zăhir dalam penafsirannya. Hal ini dinilai terlalu berlebihan bagi kelangan yang pro terhadap penafsiran kaum sufi, menurut mereka analisis para sufi tetap menyertakan makna zāhir yang mereka peroleh melalui proses ijtihadi yang merujuk pada argumentasi alQur'an, sunnah, maupun konsepsi pemakaian bahasa secara umum. Dengan landasan makna zāhir inilah para sufi membangun metode pemaknaan alQur'an secara ishärí.

Dalam pandangan para sufi, al-Qur'an bukan hanya memuat makna zăhir saja, tetapi juga mengandung pesan bătin yang tampak pada setiap ayatnya. ${ }^{11}$ Oleh sebab itu, para sufi sangat gemar dengan aspek-aspek alegoris al-Qur'an. ${ }^{12}$ Para sufi mempunyai metode khusus dalam memaknai ayat-ayat al-Qur'an, yaitu dengan menakwilkan ayat-ayat al-Qur'an secara metaforis. $^{13}$ Menurut Anwar Syarifuddin, hal itu dikarenakan dalam pandangan para mufassir sufi, setiap ayat al-Qur'an mengandung empat makna: yaitu makna zăhir, bàtin, hadd, dan matla'. Makna zăhir ayat adalah sebagai bacaannya, bàtin ayat adalah takwilnya, hadd adalah hukum-hukum tentang halal dan haram, sedangkan matla' adalah tujuan Allah dari hambaNya dengan ayat itu sendiri. ${ }^{14}$ Manna' al-Qațtan dalam bukunya "Mabāhith fí 'Ulüm al-Qur'àn" berpendapat bahwa seorang mufassir dari kalangan sufi sebelum menafsirkan al-Qur'an harus menjalankan riyādah rūhāniyah agar memperoleh pengetahuan (ma'rifah) sampai mencapai tingkatan yang disebut kashäf, di mana dengan kashäf tersebut dapat menyingkap isyaratisyarat halus yang terkandung dalam al-Qur'an. ${ }^{15}$

Dari pemaparan di atas, tulisan ini akan membahas bagaimana sebenarnya diskursus penafsiran sufistik dan sejarah pertumbuhan dan pekembangannya?

\section{Tafsir sufistik}

10 M. Anwar Syarifuddin, "Menimbang Otoritas Sufi dalam Menafsirkan Al-Qur'an”, Jurnal Studi Agama dan Masyarakat, Vol. 1, no. 2, (2004): 1.

${ }^{11}$ Al-Sirāj al-Ṭūsi, al-Lumā' (Kairo: Dār al-Kutūb al-Hadithah, 1960), 106-107.

12 Annabel Keeler, "Ṣūî̀ tafsìr as Mirror: al-Qushayrì the Murshid in his Lațā'if al-Ishārāt", Journal of Qur'anic Studies, Vol. 8, No. 1 (2006), 1. http://www.jstor.org/stable/25728196 . (diakses 22 Maret, 2014).

${ }^{13}$ Kāmil Musṭafā al-Shibli, al-Silāh baina al-Tasawwuf wa al-Tasyayyu' (Kairo: Dār alMa‘ārif, 1958), 416.

14 M. Anwar Syarifuddin, "Hermenetika Sufi Sahl Ibnu Abdullah Al-Tustari" dalam Kusmana dan Syamsuri (eds), Pengantar Kajian Al-Qur'an: Tema Pokok, Sejarah dan Wacana Kajian (Jakarta: PT Pustaka Al-Husna Baru, 2004), 249.

${ }^{15}$ Mannā' al-Qaț̣̄ān, Mabāhith fì 'Ulùm al-Qur'ān, 347. 
Tafsir merupakan mașdar dari kata fassara-yufassiru-tafsiran yang bermakna menafsirkan. Dalam al-Qur'an kata tafsir disebutkan dalam Q.S. al-Furqān ayat ke-33 dan QS. al-Nisā' ayat ke-59. Dalam pengertian etimologi, tafsir memiliki beberapa makna, di antaranya al-iḍ̆h (keterangan), al-bayān (penjelasan), ${ }^{16}$ al-kashf (mengungkap). ${ }^{17}$ Ibnu Manżür menjelaskan dalam "Lisān al- 'Arab" bahwa kata tafsira dapat didefenisikan sebagai "aktifitas mencari tahu penyebab suatu penyakit". ${ }^{18}$ Naṣr Abū Zayd menuturkan bahwa terdapat dua syarat yang diperlukan dalam menafsirkan al-Qur'an, yaitu: adanya obyek berupa tafsira serta aktifitas observasi atau analisis di dalamnya. Ia menganalogikan seorang mufassir dengan dokter, menurutnya seorang dokter tidak akan sampai kepada diagnosis terhadap suatu penyakit jika ia tidak memiliki pengetahuan yang cukup terhadap objek penelitiannya tersebut. ${ }^{19}$

Al-Zarkashì dalam "al-Burhān fí 'Ulüm al-Qur'ān" mengatakan bahwa tafsir secara terminologis merupakan suatu ilmu yang digunakan untuk memahami al-Qur'an yang diturunkan kepada Nabi Muhammad, serta menjelaskan makna-makna, hukum-hukum dan hikmah-hikmah yang terkandung di dalamnya. ${ }^{20}$ Adapun tafsir menurut al-Dhahabì adalah maksud dari kalāmullāh sesuai dengan kadar kemampuan mufassir. ${ }^{21}$ Dari definisi tersebut, mengindikasikan bahwa tafsir al-Qur'an memberikan ruang tanpa batas kepada siapapun untuk menafsirkan al-Qur'an sesuai dengan latar belakang keilmuan yang dimilikinya.

Adapun kata sufi jika ditinjau secara etimologis memiliki banyak arti, ada yang menyebut kata tersebut berasal dari kata suffah yang berarti serambi masjid Nabawi. Ada pula yang mengatakan bersumber dari kata safá, yang berarti bersih atau jernih. ${ }^{22}$ Mayoritas para ahli berpendapat bahwa kata sufi berasal dari süf yang bermakna pakaian berbahan bulu domba. Adapun orang yang berpakaian dari bulu domba disebut mutasawwif, sedangkan perilakunya disebut tașawwuf. ${ }^{23}$ Pemaknaan ini

\footnotetext{
16 Muhammad Ḥusayn al-Dhahabi, Al-Tafsïr wa al-Mufassirun (Kairo: Maktabah Wahbah, 2000), Jilid I, 12.

17 Jalāl al-Dīn al-Șuyūṭi, Al-Itqān fí 'Ulūm al-Qur'ān (Kairo: Maktabah wa Maṭba'ah alMashhad al-Ḥusyni, 1967), Jilid. II, 173.

${ }^{18}$ Ibon Manzūur, Lisān al- 'Arab (Kairo: Dār al-Ma‘āirif, t.t), Jilid 5, 3412-3413.

19 Nașr Hāmid Abū Zayd, Mafhūm al-Nash (Kairo: Matba'ah al-Hayāt al-Misriyyah li 'Ammat al-Kitāb, 1993), 284.

${ }^{20}$ Badr al-Dīn Muhammad al-Zarkashì, Al-Burhān fí 'Ulūm al-Qur'ān (Kairo: Maktabah Dār al-Turāth, t.th), Jilid II, 148.

${ }^{21}$ Muhammad Husayn al-Dhahabi, Al-Tafsìr wa al-Mufassirun, Jilid I, 59.

22 Muhammad Husayn al-Dhahabi, Al-Tafsir wa al-Mufassirun, Jilid II, 236.

${ }^{23} \mathrm{Hal}$ ini didasarkan pada Hadis Nabi yang diriwayatkan oleh Anas bin Malik:
} 
merujuk pada orang-orang yang menjalani hidup zuhud dari hal-hal duniawi serta tekun beribadah untuk membersihkan jiwa mereka, yang sekarang dikenal dengan kaum sufi. Pemilihan pakaian kasar dari bulu domba ini sebagai simbol kesederhanaan dan bentuk perlawanan terhadap perilaku orang-orang kaya yang sering memakai sutera. ${ }^{24}$ Dari sinilah kemudian muncul istilah sufistik untuk memberikan kata sifat dari kata șüfí.

Menurut Ibrāhīm Hilāl, tasawuf secara terminologi adalah memilih jalan hidup secara zuhud serta menjauhkan diri dari gemerlap kehidupan di dunia. Tak cukup sampai di situ, Ibrāhīm Hilāl menambahkan bahwa seorang sufi harus melakukan berbagai macam ibadah untuk menundukkan jasmani seseorang agar sampai kepada hakikat kesempurnaan rohani dan mengenal Allah dengan segala kesempurnaannya. ${ }^{25}$

Ibnu khaldun berpendapat bahwa tasawuf adalah ibadah kepada Allah secara terus-menerus dengan mengerahkan seluruh waktu untuk-Nya, menjauhi gemelap dunia dengan seluruh keindahannya, zuhud terhadap seluruh kecenderungan manusiawi serta menyendiri atau ber-khalwăt dalam keheningan untuk beribadah. ${ }^{26}$

Ibrāhīm Bashūni mengatakan bahwa tasawuf merupakan suatu kesadaran fitriyah yang mendorong seseorang untuk ber-mujāhadah melakukan munajat sampai ia merasakan konektivitas (wuṣūt) dengan Allah. $^{27}$

Senada dengan Ibrāhīm Bashūni, Harun Nasution menyatakan bahwa intisari dari tasawuf adalah kesadaran akan adanya komunikasi serta dialog antara ruh manusia dan Tuhan dengan mengasingkan diri (khalwat), sehingga mereka dapat mengenal Tuhan (ma'rifah). Lebih lanjut Harun Nasution mengatakan bahwa landasan filsafat tasawuf adalah Tuhan bersifat Immateri dan Maha Suci. Oleh karena itu, unsur dari manusia yang dapat bertemu dengan Tuhan adalah unsur immateri manusia, yaitu ruh, dan ruh

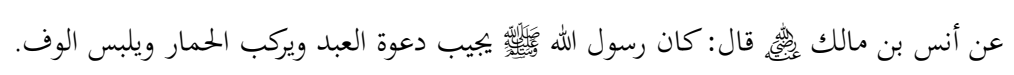

Dari Anas ibn Malik berkata: "Rasulullah saw. menyukai seseorang yang menyeru agama Allah, menunggangi keledai dan memakai pakaian yang terbuat dari bulu domba". Untuk lebih detailnya lihat M. Amin Syukur, Menggugat Tasawuf; Sufisme dan Tanggung Jawab Abad 21 (Yogyakarta: Pustaja Pelajar, 2002) 8-9.

${ }^{24}$ Harun Nasution, Falsafat dan Mistisme dalam Islam (Jakarta: Bulan Bintang, 1992), 57.

${ }^{25}$ Ibrāhīm Hilāl, al-Tasạwwuf al-Islāmi baina al-Dīn wa al-Falsafah (Kairo: Dār al-Nahḍah al-'Arabiyah, 1979), 1.

${ }^{26}$ Ibn Khaldun, Muqaddimah Ibn Khaldun (Beirut: Dār al-Qalām, 1981), 467. 28.

${ }^{27}$ Ibrāhīm Bashūnì, Nash'at al-Tașawwuf al-Islāmi (Kairo: Dār al-Ma'ārif bì al-Miṣr, t.th), 
tersebut haruslah suci. Karena yang dapat mendekat kepada Yang Maha Suci adalah jiwa yang suci. ${ }^{28}$

Dari pemaparan di atas, dapat disimpulkan bahwa sufi atau tasawuf pada intinya adalah upaya seseorang melatih jiwa dengan ber-mujāhadah melakukan berbagai 'amaliyah yang dapat membebaskan dirinya dari pengaruh kemilau duniawi agar lebih mendekatkan diri kepada Allah.

jika kedua kata tafsir dan sufi digabungkan, maka tafsir sufistik dapat bermakna menakwilkan ayat-ayat al-Qur' an yang berpijak pada makna di balik zāhir ayat dengan mengemukakan isyarat halus yang hanya tampak pada orang yang telah menempuh jalan sulü $\bar{k}^{29}$ dan bentuk riyădah lainnya dalam tasawuf, tetapi memungkingkan adanya perpaduan antara isyarat yang tersembunyi dengan makna yang dimaksud ayat secara zāhir. ${ }^{30}$ Dari pengertian tersebut terlihat bahwa tafsir sufistik dapat dibentuk dari pemahaman seseorang terhadap ayat-ayat al-Qur'an yang bercorakkan tasawuf yang muncul dari pemahaman tasawuf itu sendiri.

Artinya, tafsir sufistik merupakan salah satu corak tafsir yang tidak terikat dengan makna nașh secara lahir saja, tetapi lebih cenderung mengungkap isyarat-isyarat makna bătin dari ayat-ayat al-Qur'an melalui jalan takwil. Tentu saja isyarat-isyarat makna tersebut diarahkan pada konsep dan pengalaman sufistik yang diperoleh penafsirnya, karena memang mufassir-nya adalah seorang sufi.

\section{Pertumbuhan dan Perkembangan Tafsir Sufi}

Pertumbuhan tafsir sufistik tidak terlepas dari perkembangan tasawuf itu sendiri. Menurut al-Dhahabi, perilaku tasawuf sudah ada sejak masa Nabi dan para sahabat, beberapa sahabat pada saat itu cenderung meninggalkan kenikmatan duniawi. Mereka lebih senang hidup dalam kezuhudan, bersungguh-sungguh dalam beribadah, mengisi malam mereka dengan qiyām al-laīl, sedangkan siang mereka diisi dengan puasa sebagai bagian dari riyạdah rūhaniyyah. Tetapi, pada saat itu belumlah dikenal istilah tasawuf dan orang yang menjalankannya disebut dengan sufi. Istilah

\footnotetext{
${ }^{28}$ Harun Nasution, Islam Rasional; Gagasan dan Pemikiran (Bandung: Mizan, 1995), 360.

${ }^{29}$ Kata sulūk berasal dari terminologi al-Qur'an Faslukí dalam surat al-Nahl ayat 69, "Fasluki subula rabbiki dhalulā", yang artinya tempulah jalan Tuhanmu yang telah dimudahkan (bagimu). Dan seseorang yang menepuh jalan sulük disebut sălik. Dalam kaitannya dalam dunia tarekat sulūk berarti latihan atau riyā dimana tujuan awal dari suluk adalah tazkiyah al-nafs yang kemudian meningkat kepada jenjang maqām tertentu sesuai dengan tradisi tarekat tersebut. Lihat Mahyuddin, Kuliah Akhlak Tasawuf (Jakarta: Kalam Mulia, 2003), 119. Lihat juga A. Rivay Siregar, Tasawuf; Dari Sufisme Klasik ke Neo-Sufisme (Jakarta: Raja Grafindo Persada, 2002), 281.

${ }^{30}$ Muhammad Ḥusayn al-Dhahabi, Al-Tafsìir wa al-Mufassirun, Jilid II, 261.
} 
tasawuf sendiri baru muncul pada abad kedua hijriah yang dikenalkan pertama kali oleh Abu Hāshim al-Ṣūfi (w. 150 H). Dengan demikian, perilaku tasawuf inilah yang menjadi acuan utama dalam tafsir sufistik. ${ }^{31}$

Ignaz Goldziher menuturkan bahwa penafsiran yang dilakukan oleh para sufi dipengaruhi oleh visi tasawuf yang bertumpu pada perenungan makna al-Qur'an secara umum, dari perenungan itu kemudian mereka mempunyai kecenderungan untuk mampu menemukan pondasi dalam mengkonstruksikan mazhab mereka dalam al-Qur'an, dan menegakkan bukti bahwa prinsip-prinsip tertentu dalam mazhab mereka disandarkan pada alQur'an. ${ }^{32}$

Selain itu, kemunculan penafsiran sufistik ini juga tidak lepas dari situasi dan kondisi yang melatar belakangi corak dan sifat gerakan tasawuf itu sendiri pada masa setelah wafatnya Rasulullah Saw. Sebagaimana yang dikemukakan oleh Muhammad Iqbal dalam "The Reconstruction of Religious Thought in Islam" yang dikutip oleh Anwar Syarifuddin, bahwa tasawuf merupakan sebuah protes bisu melawan kekuat an politik aristokrasi, ketidakadilan sosial, dogma-dogma agama yang cenderung formal dan kering. Menurut Iqbal, di sinilah para sufi dianggap telah berhasil menyelamatkan warisan spiritual Islam. Lebih dari itu, para sufi juga telah memberikan warna baru bagi khazanah penafsiran al-Qur'an ketika mereka mampu menunjukan orisinalitas tasawuf sebagai ajaran Islam. ${ }^{33}$

Jika menengok ke belakang, penafsiran sufistik sejatinya sudah ada sejak masa Nabi saw., sebagaimana yang diisyaratkan dalam sebuah hadis Nabi Saw.:

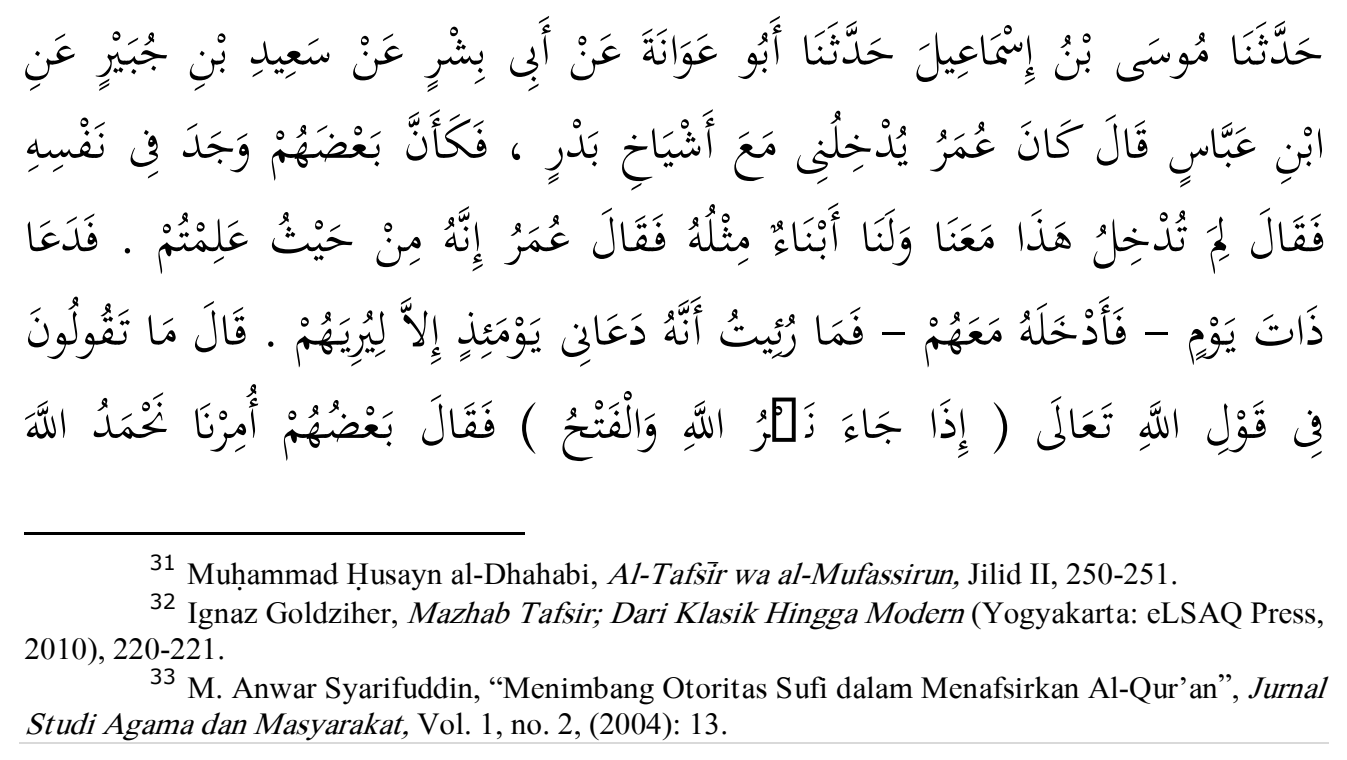

121 | TamaddunVol. 7 , No. I, Januari - Juni 2019 


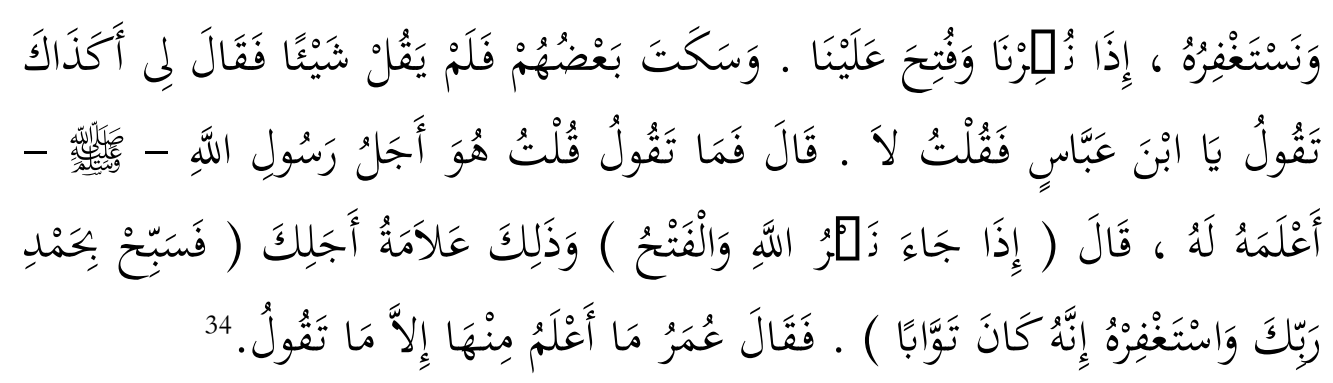

"Diriwayatkan dari Mūsā Ibn Ismāìil, dari Abū 'Awānah, dari Abì Bishr dari Sa īd Ibn Jubayr dari Ibn 'Abbās berkata: "Suatu ketika 'Umar Ibn Khațāa membawa saya masuk (singgah) bersama sahabat-sahabat senior yang ikut dalam peperangan Badar, maka seolah-olah sebagian mereka marah terhadap 'Umar dan berkata "Mengapa engkau ajak dia (Ibn 'Abbās) bersama kita padahal kami mempunyai anak seumur dia". Maka berkata Umar: "Kalian telah mengenal siapa dia (Ibn 'Abbas)". Maka 'Umar memanggil Ibn 'Abbas pada suatu hari dan mengajak bergabung bersama mereka. (Ibn 'Abbas berkata) "Tidaklah 'Umar memanggilku kecuali untuk memperlihatkan kepada mereka (kelebihanku)". Umar berkata: "Bagaimana pendapat kalian tentang firman Allah 'Idhā jā', anașrullāhi wa al-fatḥ"? Maka sebagian mereka menjawab: "Kita diperintahkan untuk memuji Allah dan meminta ampun kepada-Nya apabila kita ditolong dan diberikan kemenangan kepada kita" dan sebagian lain diam tidak menjawab sedikitpun. Maka Umar berkata kepadaku: "Apakah demikian juga pendapatmu wahai Ibn 'Abbās?" Maka aku menjawab "Bukan". Kemudian 'Umar berkata: "Bagaimana pendapatmu?". Aku berkata: "Ayat tersebut adalah tanda dari ajal Rasulullah saw. Allah memberitahu kepada Nabi mengenai ajalnya. Dan demikian pula mengenai ajalmu (fasabbih bihamdi Rabbika wa astaghfirh innahū kāna tawwābā). Maka 'Umar berkata "Aku tidak mengetahui tentang ayat ini kecuali apa yang kamu katakan".

Pada hadis atas, terdapat beberapa sahabat yang mencoba memberikan penafsiran terhadap ayat ke-1 surah al-Nașr dengan mengatakan bahwa ayat tersebut merupakan perintah kepada manusia untuk senantiasa

\footnotetext{
${ }^{34}$ Muhammad ibn Ismā'ìil al-Bukhārì, Sahīh al-Bukhārīi (Kairo: Dār al-Ḥadith, 2004), Jilid. III, kitab Tafsir al-Qur'an, bab Surat idhā jā' a nashrullāh, no. hadis 4970, h. 339.
} 
bersyukur kepada Allah dan meminta ampunan-Nya. Berbeda dengan para sahabat yang lain, Ibn 'Abbās mengatakan bahwa ayat tersebut adalah sebagai tanda ajal Rasulullah Saw.

Contoh penafsiran sufistik lain yang dilakukan oleh para sahabat adalah ketika diturunkannya ayat ke-3 surah al-Mā'idah, ${ }^{35}$ sebagaimana hadis yang diriwayatkan oleh Abi Shaybah di bawah ini:

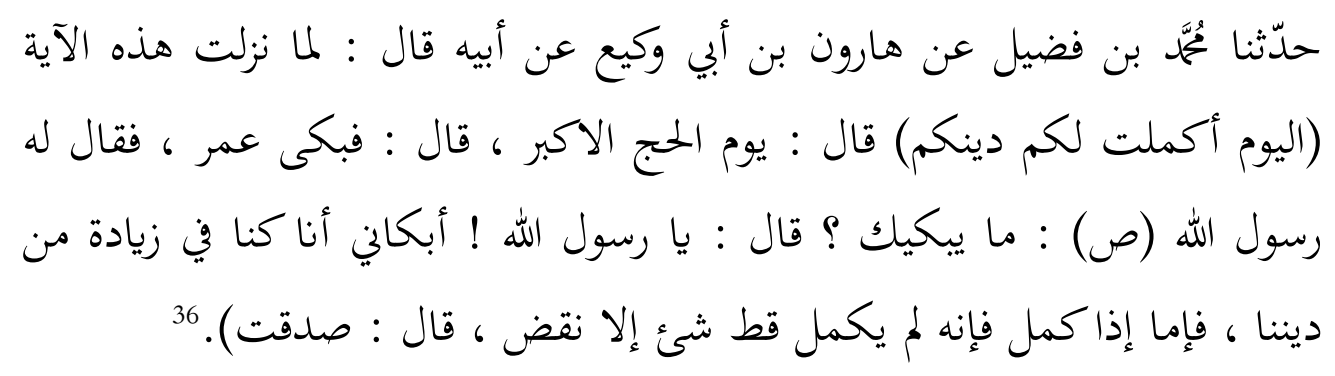

"Diberitakan kepada kami dari Muhammad ibn Fudayl dari Hārūn bin Abī Wakì' dari Ayahnya berkata: 'Umar Ibn Khattāb menagis ketika diturunkan ayat ke-3 surah al-Mā'idah, maka Nabi berkata kepadanya: 'Apa yang membuatmu menangis?'. 'Umar menjawab:' Agama kita telah sempurna, tetapi bila agama tersebut sudah sampai kepada titik puncak kesempurnaan, maka di atas itu tidak ada lagi yang lain, kecuali suatu kemunduran'. Kemudian Nabi berkata: 'Kamu benar'.

Pernyataan 'Umar pada hadis di atas merupakan ungkapan kesedihan yang ia rasakan karena isyarat halus yang ia tangkap dari ayat ke-3 surah alMà'idah bahwa pertanda pengajaran Nabi tentang agama Islam akan berakhir. Dari beberapa riwayat di atas, terlihat bahwa penafsiran corak sufistik telah ada sejak masa awal perkembangan Islam.

Geneologi tafsir sufi mempunyai riwayat yang panjang, kecenderungan orang untuk berfikir secara sufistik telah ada sejak tumbuh pesatnya berbagai ilmu pengetahuan di zaman dinasti 'Abbasiyah, ${ }^{37}$ tetapi penulisan tafsir bercorak sufistik yang ditulis secara sistematis baik secara

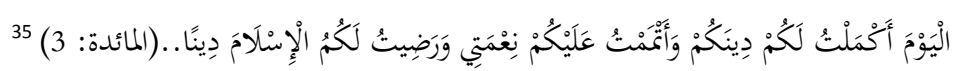

"Pada hari ini telah Aku sempurnakan agamamu untukmu, dan telah aku cukupkan nikmat-Ku bagimu, dan telah aku ridhoi Islam sebagai agamamu..” (Q.S. al-Mā'idah [5]: 3)

${ }^{36}$ Abì Bakr 'Abdillāh bin Muhammad bin Abī Shaybah, al-Mușșannaf Li Ibn Abī Shaybah (Jeddah: Dār al-Qiblah, 2006), Juz 19, Hadis No. 35549, Kitāb al-Zuhd, 118.

${ }^{37}$ Mannā' al-Qaț̣̄ān, Mabāhith fì 'Ulüm al-Qur'ān, 326-333. 
tematis atau mencakup keseluruhan ayat-ayat al-Qur'an barulah muncul beberapa waktu kemudian.

Mufassir pertama yang menafsirkan al-Qur'an dengan corak sufistik adalah Sahl ibn Yūnus ibn 'Isā ibn 'Abdillah ibn Rafí' al-Tustarī. Ia dilahirkan di Tustar, sebuah desa yang berada si wilayah Ahwaz, propinsi Khuzistan, Persia, pada tahun $200 \mathrm{H}$. menurut riwayat lain menyebutkan $201 \mathrm{H}$. Tokoh sufi yang lebih dikenal dengan sebutan al-Tustari ini pernah bertemu dan menimba ilmu dari seorang sufi terkenal Dhū al-Nūn al-Misrì. Al-Tustari menghabiskan sebagian hidupnya di Basrah sampai ia meninggal di tempat yang sama pada tahun $283 \mathrm{H}^{38}$

Karya al-Tustari yang paling fenomenal adalah Tafsir al-Qur'an al'Azim, tafsir ini dianggap sebagai karya tertua yang berkenaan dengan tafsir sufi. Dalam kitab ini, al-Tustari tidak menafsirkan semua ayat al-Qur'an, tapi hanya ayat-ayat tertentu saja yang ditafsirkannya, karena ayat-ayat tersebut dianggap mengandung petunjuk atau isyarat yang tersembunyi disamping makna zāhir-nya. Meskipun tafsir ini berukuran kecil, tetapi dianggap sebagaian kalangan sebagai tafsir sufi yang sangat istimewa. ${ }^{39}$

Dalam muqaddimah tafsirnya, al-Tustari mengkalsifikasikan empat aspek yang berhubungan dengan al-Qur'an: Pertama, al-Qur'an terdiri dari informasi, berita, tidak hanya cerita tentang masyarakat terdahulu, tapi juga tentang prediksi terhadap yang akan terjadi di masa mendatang. Kedua, alQur'an mengandung ajaran agama. Dengan ajaran agama ini manusia bisa menyembah Tuhan dan khusus orang tertentu, mereka bisa mengkomunikasikan secara langsung dengan Tuhan melalui jalan ma'rifah. Ketiga, al-Qur'an adalah petunjuk. Dengan petunjuk tersebut Tuhan menunjukan jalan yang lurus kepada hamba-Nya agar mereka selamat. Keempat, al-Qur'an adalah firman Tuhan yang sudah ada dalam laụ̣ maḥüz sebelum penciptaannya. Lebih lanjut, dari karakter tanzīl (proses pewahyuan) al-Qur'an, al-Tustarì mengkalsifikasikan al-Qur'an menjadi lima bagian: ayat yang jelas (muḥkam), ayat yang samar (mutashābih), ḥalāl, harām, dan kiasan (amthā). Kemudian al-Tustari menjelaskan bahwa ayat muhkkam harus dipraktekan dan ayat mutashäbih harus diyakini. Halal dan haram harus dipatuhi serta diikuti, dan amthāl harus senantiasa direnungkan. ${ }^{40}$

38 M. Anwar Syarifuddin, "Hermenetika Sufi Sahl Ibnu Abdullah Al-Tustari" dalam Kusmana dan Syamsuri (eds.), Pengantar Kajian Pengantar Kajian Al-Qur'an: Tema Pokok, Sejarah dan Wacana Kajian (Jakarta: PT Pustaka Al-Husna Baru, 2004), 234-240.

39 M. Anwar Syarifuddin, "Hermenetika Sufi Sahl Ibnu Abdullah Al-Tustari", 243.

40 M. Anwar Syarifuddin, "Hermenetika Sufi Sahl Ibnu Abdullah Al-Tustari", 247-248. 
Konsep umum interpretasi al-Tustari dapat ditemukan dalam perkataannya bahwa masing-masing ayat al-Qur'an mempunyai empat tingkatan makna: zāhir, bătin, hadd, dan mațla'. Al-Tustari melanjutkan bahwa zăhir adalah bacaan (tilāwah), bätin adalah pemahaman (fahm), adapun hadd adalah hal-hal yang dibolehkan dan yang dilarang (halaluhā wa haramuhāa), dan matla' adalah pencapaian hati terhadap maksud dari ayat alQur'an sebagai suatu pemahaman yang datang dari Allah swt. (ishräf al-qalb 'alā al-murād bihā faqahan minallāh 'azza wa jalla). ${ }^{41}$ Dari konsep umum interpretasi tersebut, model interpretasi yang terdapat dalam Tafsir alTustari dapat diklasifikasikan ke dalam tiga bentuk. Pertama, interpretasi literal (lughawi $\bar{i}$ ) yang menunt un kepada penjelasan sebuah ayat menurut arti zāhir. Kedua, interpretasi alegoris (ishārî̉) yang menggabungkan interpretasi literal berdasarkan makna zăhir-nya dengan penajaman bătin. Dengan kata lain, ayat al-Qur'an ditafsirkan dengan cara membuat asosiasi antara zāhir yang nampak dan bătin yang tersembunyi dalam kerangka ta'wìl. Ketiga, interpretasi simbolis yang mendorong makna bătin memahami ayat alQur'an yang tidak ditemukan indikasi zăhir-nya. Dalam kerangka ta'wìl tersebut, al-Tustari membuat simbolisasi huruf yang membentuk kata. ${ }^{42}$

Selanjutnya, muncullah tafsir Haqā'iq al-Tafsìryang ditulis oleh Abū 'Abd al-Raḥmān Muhammad ibn Ḥusaīn ibn Musāal-Azdi al-Sulamī yang lebih dikenal dengan sebutan al-Sulamī. Al-Sulami lahir pada tahun $330 \mathrm{H}$. dan wafat pada tahun $412 \mathrm{H}$. Ia adalah seorang syaikh sufi dan seorang 'àlsim di wilayah Khurasan. Selain seorang sufi, ia juga dikenal sebagai seorang muhaddith. Ia menghabiskan tidak kurang dari 40 tahun untuk menulis hadis. Tidak heran jika banyak dari para pengkaji hadis yang mengambil hadis darinya, sebut saja Ḥākim Abū 'Abdillāh, Abū al-Qasīm al-Qushayri pernah belajar dan mengambil hadis darinya. Al-Sulami dikenal sebagai seorang sufi yang sangat produktif, tercatatat tidak kurang dari seratus judul kitab yang pernah ia tulis, mulai dari masalah tasawuf, tärikh, hadis dan tafsir. ${ }^{43}$

Haqā'iq al-Tafsir mencakup semua surat dalam al-Qur'an, tetapi hanya ayat-ayat tertentu saja yang ditafsirkan oleh al-Sulamì. Dalam menafsirkan ayat, al-Sulami hanya memaknai dengan makna batin yang terkandung dalam ayat tersebut. Meski demikian, bukan berarti ia menolak makna zăhir dari setiap ayat, ini bisa dilihat dari pernyataan al-Sulami yang mengatakan bahwa ia hanya ingin menghimpun tafsir ahli hakikat ke dalam

\footnotetext{
${ }^{41}$ Muhammad Husayn al-Dhahabi, Al-Tafsir wa al-Mufassirun, Jilid II, 282.

42 M. Anwar Syarifuddin, "Hermenetika Sufi Sahl Ibnu Abdullah Al-Tustari", 252-253.

${ }^{43}$ Mani' 'Abd al-Halim Maḥmūd, Manhāj al-Mufassirin, 150-152. Lihat juga Muhammad Husayn al-Dhahabi, Al-Tafsìr wa al-Mufassirun, Jilid II, 284.
} 
kitab khusus sebagaimana yang dilakukan oleh ahli zāhir terhadap tafsir zāhirí. ${ }^{44}$ Dari perkataan al-Sulamì tersebut, terlihat bahwa apa yang ditulis dalam tafsirnya merupakan kumpulan pendapat dari para ahli tasawuf yang disusun sesuai dengan tartīb al-Qur'an. Adapun ahli tasawuf yang banyak dikutip pendapatnya oleh al-Sulamī adalah Ja'far ibn Muhammad al-Șādiq, Ibn 'Athāillah al Sakandari, Junayd al-Baghdādi, Fudhayl ibn 'Iyādh, Sahl al-Tustāīi. ${ }^{45}$

Keberadaan tafsir al-Sulamì mengundang beragam penilaian dari berbagai kalangan, di antaranya Jalāl al-Dīn al-Suyūți (w. $911 \mathrm{H}$ ) dalam kitabnya al-Itqān fì 'Ulüm al-Qur'ān ia mengungkapkan bahwa perkataan para sufi terhadap al-Qur' an bukanlah sebuah tafsir. ${ }^{46}$ Selain itu, Abu Ḥasān al-Wāhidi (w. 468 H) pernah mengungkapkan ketidaksetujuannya terkait tafsir karya "Abd al-Rahmā̄n al-Sulāmī yang menggunakan pendekatan ishāri, ia mengatakan bahwa siapapun yang mempercayai tafsir tersebut berarti ia telah keluar dari Islam. ${ }^{47}$ Dari perkataan al-Wāhidì dan al-Suyūṭî, terkesan bahwa mereka hanya memahami istilah tafsir dengan cara sangat formal melalui dimensi legalistik serta teologis yang sangat kental. ${ }^{48}$

Berbeda dengan al-Wāhidi dan al-Suyūṭị, Māni' 'Abd Ḥalim Mahmūd berpendapat bahwa apa yang ditulis oleh al-Sulami merupakan ilham dan kata hati yang berhubungan dengan kebersihan jiwa, akhlak mulia, ibadah dan lainnya, tidak berhubungan dengan zāhir ayat yang ditafsirkan. Menurutnya, hal tersebut dikarenakan para sufi tidak pernah menamakan apa yang mereka tulis sebagai sebuah penafsiran, tetapi sebuah ilham dari Allah swt. yang didapat setelah mereka men-tafakkur-i dan mentadabbur-i ayat al-Qur'an. Dengan kata lain, penafsiran yang sesungguhnya adalah penafsiran yang sesuai dengan asbāb al-nuzūl, sesuai dengan kaidah bahasa Arab, dan ilmu-ilmu perangkat lainnya dalam menafsirkan al-Qur' an. 'Abd Halim melanjutkan, kritikan di atas terfokus jika al-Sulami menganggap bahwa apa yang ia tulis adalah sebuah tafsir, jika tidak beranggapan demikian maka kritikan tersebut tidaklah benar. ${ }^{49}$

Setelah al-Sulami, estafet penafsiran sufistik berikutnya dilakukan oleh 'Abd al-Karīm ibn Ḥawāzan ibn 'Abd al-Malik ibn Ṭalhạ ibn Muhammad al-Qushayri (w. $465 \mathrm{H}$ ), dengan karya tafsirnya yang berjudul Lat $\bar{a}^{\prime}$ if al-Ishäràt at au yang lebih populer dengan sebutan Tafsìr al-Qushayrí.

\footnotetext{
44 Muhammad Husayn al-Dhahabi, Al-Tafsìir wa al-Mufassirun, Jilid II, 285.

45 Muḥammad Ḥusayn al-Dhahabi, Al-Tafsir wa al-Mufassirun, Jilid II, 285.

46 Jalāl al-Dìn al-Ṣuyūtị, Al-Itqā̄n fí 'Ulüm al-Qur'ān, Jilid IV, 194.

47 Taqiy al-Dīn Ibn Șalāh, Fatāwā, 29.

48 M. Anwar Syarifuddin, "Menimbang Otoritas Sufi dalam Menafsirkan Al-Qur'an", 2.

49 Mani' 'Abd al-Ḥalim Mạ̣mūd, Manhāj al-Mufassirīn (terj.), 153-154.
} 
Sebagaimana al-Sulamī, al-Qushayrī juga menggunakan metode yang sama dengan gurunya itu dalam usaha memahami ayat-ayat al-Qur'an. Di samping itu, dalam menafsirkan al-Qur'an ia berusaha agar tetap mengacu kepada syariat, dalam hal ini adalah al-Qur'an dan Hadis. ${ }^{50}$ Selain itu, al-Qushayri juga selalu berpegang pada perangkat ilmu-ilmu tafsir, seperti ilmu bahasa Arab, Nahwu, dan perangkat ilmu tafsir lainnya. ${ }^{51}$

Tafsir sufistik yang muncul pada perkembangan selanjutnya adalah tafsir al-Qur'ān al-'Azīm karya Abū Bakar Muhammad ibn 'ATi ibn Muhammad ibn Ahmad ibn 'Abdillah al-Ṭâ'I al-Ḥâtimì yang lebih dikenal dengan nama Ibn 'Arabì. Ia dilahirkan pada 17 Ramaḍān 560 H, di Mursia, Spanyol bagian tenggara. Pada waktu kelahirannya, Mursia diperintah oleh Muhammad ibn Sa'id ibn Mardanīsh. ${ }^{52}$ Ibn 'Arabi wafat di Damaskus pada tahun $638 \mathrm{H}^{53}$

Paham wahdat al-wujūd sangat diidentikan dengan Ibn 'Arabī, sekalipun ia sendiri tidak pernah menggunakan istilah waḥdat al-wuju. $d^{54}$ Bahkan oleh beberapa kalangan, ia dianggap sebagai pendiri doktrin wahdat al-wujūd, karena ajaran-ajarannya mengandung ide wahdat al-wujūd. Beberapa pernyataannya yang disinyalir mengandung ide wahdat al-wujū di antaranya: "Semua wujud adalah satu dalam realitas, tiada sesuatu pun bersama dengannya", "Wujud bukan lain dari al-Haqq karena tidak ada sat upun dalam wujud selain Dia", "Entitas wujud adalah satu, tetapi hukumhukumnya beraneka". 55 maka tidak mengherankan jika melihat contoh penafsirannya akan ditemukan indikasi bahwa penafsirannya itu banyak dipengaruhi teori wahdat al-wujūd, sebagaimana ketika ia menafsirkan ayat kesatu surat al-Nisā':

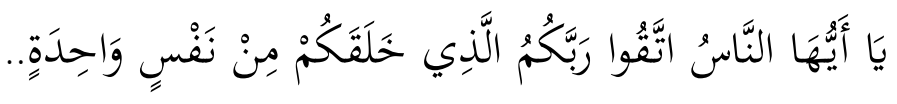

50 Jawid A. Mojaddedi, "Legitimizing Sufism in al-Qushayri's Risala”, Studia Islamica, No. 90 (2000), 46, http://www.jstor.org/stable/1596163. (diakses 4 Maret, 2014). Lihat juga Kristin Zahra Sands, Süfí Commentaries on The Qur'ān in Classical Islam, (New York: Routledge, 2006), 71.

${ }^{51}$ Mani' 'Abd al-ḤaTim Maḥmūd, Manhāj al-Mufassirīin (terj.), 184.

${ }^{52}$ Kautsar Azhari Noer, Ibn Al-'Arabí; Wahdat al-Wujüd dalam Perdebatan (Jakarta: Paramadina, 1995), 17.

${ }^{53}$ Muṣtafā ibn Sulaymān dalam Muqaddimah-nya, Sharh Fuṣuṣs al-Hikām (Beirut: Dār alKutūb al-'Ilmiyah, 2007), 9.

${ }^{54}$ Doktrin wah̆dat al-wujūd telah dicetuskan oleh Ma'rūf al-Karkhì (w. 200 H.) seorang sufi ternama asal Baghdad jauh sebelum Ibn al-'Arabì, dianggap pertama kali mempelopori wahdat alwujū karena al-Karkhi pernah mengungkapkan syahadat dengan kata-kata: "Tiada sesuatu pun dalam wujud kecuali Allah". Lihat Kautsar Azhari Noer, Ibn Al-'Arabī; Wahdat al-Wujūd dalam Perdebatan, 34-35.

${ }^{55}$ Kautsar Azhari Noer, Ibn Al- 'Arabī; Wahdat al-Wujūd dalam Perdebatan, 35. 
"Wahai sekalian manusia! Bertaqwalah kepada Tuhanmu yang menciptakan kalian dari satu jiwa..”(Q.S. al-Nisā' [4]: 1).

Dalam menafsirkan ayat di atas, Ibn 'Arabī mengatakan: "Bertaqwalah kepada Tuhanmu. Jadikan bagian yang zăhir dari dirimu sebagai penjagaan bagi Tuhanmu. Dan jadikanlah bagian batinmu -yang adalah Tuhanmu- sebagai penjaga bagimu, karena perkaranya adalah perkara celaan dan pujian. Jadilah kalian pemeliharanya dalam celaan, serta jadikanlah Dia pemelihara kalian dalam pujian, niscahya kalian akan menjadi orang-orang yang beradab diseluruh alam". ${ }^{56}$ Dari penafsiran Ibn 'Arabì tersebut, terlihat tidak adanya keterkaitan antara makna zāhir dengan makna batin ayat, bahkan terkesan Ibn 'Arabi lebih menampakan makna yang berseberangan dengan makna zāhir ayat. Selain itu, terlihat pula bagaimana ide waḥdàt al-wujūd sangat kental sekali tergambar dalam penafsirannya.

Tafsir sufistik yang muncul selanjutnya adalah 'Arä'is al-Bayān fí Haqā'iq al-Qur'ān karya Abū Muḥammad Ruzbihān Ibn Abī al-Nașr alBaqali al-Shïrāzì. Ia meninggal pada tahun $666 \mathrm{H}^{57}$ Dalam menafsirkan ayat al-Qur'an, al-Shïrāzì lebih menonjolkan makna ishärí. Mesikipun demikian, ia tetap mengakui pentingnya pemaknaan al-Qur'an secara zāhir sebelum mengungkap sisi esoteris dari ayat al-Qur'an. Sebagaimana yang ia nyatakan dalam muqaddimah 'Arā'is al-Bayān fí Haqà'iq al-Qur'ān bahwa tidak akan pernah usai usaha manusia dalam menyibak makna al-Qur'an baik secara zăhir dan bătin, tidak ada pemahaman yang sempurna dalam mengupas maknanya. Karena ia menyadari betul bahwa makna yang terkandung dalam setiap ayat al-Qur'an begitu luas dan dalam. ${ }^{58}$

Kemudian, muncullah tafsir sufistik al-Ta'wìlät al-Najmiyah yang terdiri dari lima jilid. Tafsir ini ditulis oleh Najm al-Dīn Dāyah, namun ia meninggal sebelum sempat menyelesaikannya. Kemudian penulisan tafsir ini disempurnakan oleh 'Alā' al-Dawlah al-Samnānī. Nama lengkap Najm alDīn Dāyah adalah Abū Bakar ibn 'Abdullah ibn Muhammad ibn Shāhid alAsadi al-Rāzì yang lebih popular dengan sebutan Dāyah. Ia wafat pada tahun $654 \mathrm{H}$ di Baghdad. Nama lengkap penulis kedua dari tafsir al-Ta'wìlāt al-Najmiyah adalah Aḥmad ibn Muḥammad ibn Aḥmad ibn Muhammad al-

\footnotetext{
56 Ibn 'Arabī, Fuṣūṣ al-Hikam (Beirut: Dār al-Kitāb al-'Arabiy, t.th), Jilid I, 50.

57 Muhammad Husayn al-Dhahabi, Al-Tafsir wa al-Mufassirun, Jilid II, 288.

58 Muḥammad Ḥusayn al-Dhahabi, Al-Tafsir wa al-Mufassirun, Jilid II, 288.
} 
Samnānī, ia biasa dijuluki dengan Alā' al-Dawlah al-Samnānī. Al-Samnānī dilahirkan pada tahun $659 \mathrm{H}$, dan wafat tahun $736 \mathrm{H}$ di Baghdad. ${ }^{59}$

Tafsir yang bercorak sufistik lainnya adalah Gharā'ib al-Qur'ān wa Raghā'ib al-Furqān karya Nizām al-Dīn al-Ḥasān ibn Muhammad al-Ḥusayn al-Khurasani al-Naysābūrì. Ia termasuk ulama yang sangat dihormati dengan kedalaman ilmu yang dimilikinya. Disamping itu, Al-Naysabūrí juga dikenal sebagai seorang sufi dengan kezuhudan dan sifat warā'-nya. Oleh karena itu, tidaklah mengherankan jika kitab tafsirnya banyak menjadi rujukan mufassir-mufassir setelahnya. Kitab tafsir Gharā'ib al-Qur'ān wa Raghä'ib al-Furqān banyak disandarkan pada tafsir al-Kabīr karya Fakhr al-Rāzi dan al-Kashāf karya al-Zamakhshari. Ia tidak hanya menukil perkataan dua mufassir besar tersebut, tetapi ia juga menampakkan keluasan pemahaman serta kekuatan akalnya sendiri. Tidak jarang pula al-Naysabūri mengkritisi pendapat kedua mufassir tersebut. Selain tinjauan tasawuf, ia juga menafsirkan ayat-ayat al-Qur' an menggunakan tinjauan fiqh, qira'at, bahasa Arab, balaghah dan kalam. ${ }^{60}$

Al-Naysabürí adalah seorang ulama yang sangat kuat karakter kesufiannya. Hal ini terlihat ketika ia menafsirkan Q.S. al-Baqarah ayat 67 berikut ini:

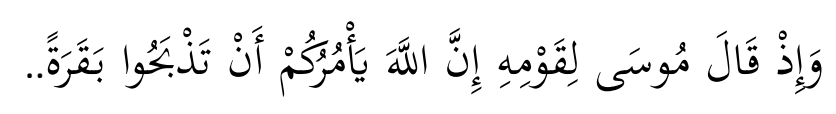

"Dan (ingatlah), ketika Musa berkata kepada kaumnya: "Sesungguhnya Allah menyuruh kalian untuk menyembelih seekor sapi betina"(Q.S. al-Baqarah [2]: 67).

Setelah al-Naysabūrì menjelaskan makna zāhir ayat di atas, kemudian ia menyebutkan bahwa yang dimaksud dengan penyembelihan 'sapi betina' adalah penyembelihan nafsu kebinatangan. Karena dalam penyembelihan itu terdapat kehidupan ruhani, itulah yang dinamakan dengan al-jihād al-akbar. ${ }^{61}$

Kemudian, tafsir bercorakkan sufistik yang muncul pada abad 12 hijriyah adalah tafsir Rūh al-Ma'ānì karya Shihāb al-Dīn al-Sayyid Muhammad al-Alūsī al-Baghdadi. Ia lahir dari keluarga yang sangat terpelajar di Baghdad pada tahun $1217 \mathrm{H}^{62}$ Al-Alūsì tumbuh dalam

\footnotetext{
59 Muhammad Husayn al-Dhahabi, Al-Tafsïr wa al-Mufassirun, Jilid II, 290-291.

60 Muḥammad Ḥusayn al-Dhahabi, Al-Tafsïr wa al-Mufassirun, Jilid I, 231-232

61 Maḥmūd Basuni Fawdah, al-Tafsìr wa Manāhijuhu (Kairo: Matba'ah al-Amānah, 1977), 260.

62 Muhammad Ḥusayn al-Dhahabi, Al-Tafsir wa al-Mufassirun, Jilid I, 250.
} 
bimbingan orang tuanya sendiri yaitu al-Suwaydi. Di samping itu, ia juga pernah menimba ilmu dari al-Naqsābandi, maka tidak heran jika penafsirannya sangat kental dengan nuansa sufi. Karena dari al-Naqsābandì lah ia mempelajari tasawuf. Pada tahun 1248 H., al-Alūsì diangkat sebagai mufti setelah sebelumnya ia menjabat sebagai wali wakaf di Madrasah alMarjaniyyah, namun pada tahun $1263 \mathrm{H}$. ia melepaskan jabatannya itu agar lebih fokus untuk menyusun tafsir al-Qur'an yang kemudian dikenal dengan tafsir Rūh al-Ma'ānī. ${ }^{63}$ Al-Alūsì wafat pada hari Jum'at bulan Dhū alQa'dah 1270 H. dan dimakamkan di samping keluarganya di Kurkhí.

Dalam menafsirkan ayat al-Qur'an, al-Alūsì menerangkan makna secara zăhir terlebih dahulu sebelum kemudian masuk ke dalam pemaknaan secara batin, serta memadukan kedua pemaknaan tersebut secara sinergis. Hal ini terlihat dari contoh penafsiran al-Alūsì pada Q.S. al-Baqarah [2] ayat 55:

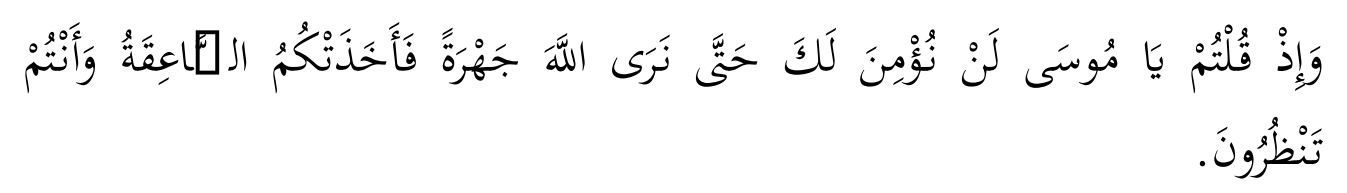

"Dan (ingatlah), ketika kamu berkata: "Hai Musa, kami tidak akan beriman kepadamu sebelum kami melihat Allah dengan terang", karena itu kamu disambar halilintar, sedang kamu menyaksikannya." (Q.S. al-Baqarah [2]: 55)

Menurut al-Alūsì, pemaknaan secari ishāri dari ayat di atas adalah: "Ketika kalian berkata, wahai inti hati, kita tidak akan beriman dengan iman yang hakiki sehingga kami sampai kepada maqam mushāhadah. Kemudian kalian tertimpa kematian yang disebut dengan fanā' dalam tajalli al-Dhāti padahal kalian menyaksikannya. Kemudian kami membangkitkan kalian dalam kehidupan yang kekal dari kehidupan sebelumnya yang fanā' agar kalian bersyukur kepada-Ku atas segala nikmat yang telah diberikan. Setelah itu Kami melindungimu dengan perlindungan sifat tajalli, karena dengan sifat tajalli tersebut dapat menghalangi dari cahaya Tuhan". ${ }^{64}$

Setelah al-Alusi, banyak tafsir-tafsir sufi muncul menghiasi khazanah penafsiran al-Qur'an. Di Indonesia sendiri ada sosok Hamka seorang ulama produktif yang banyak melahirkan karya tulisan. Di antara

\footnotetext{
${ }^{63} \mathrm{Jum}$ 'ah 'ATì 'Abd al-Qadir, Zāe al-Rāghibīn fí Manāhij al-Mufassirīn (Kairo: Kuliyah Ușūl al-Dīn Jāmi'ah al-Azhar, 1986), 127. Lihat juga Muhammad Ḥusayn al-Dhahabi, Al-Tafsìr wa alMufassirun, Jilid I, 251.

${ }^{64}$ Al-Alūsì, Rūh al-Ma’ānī, Jilid I, 262-263.
} 
karyanya yang paling fenomenal adalah Tafsir al-Azhar. Hamka sendiri lahir dari pergerakan kaum modernis yang berafiliasi dalam gerakan Muhammadiyah. Hamka yang membawa konsep baru dalam dunia tasawuf, walaupun ia bukan seorang sufi yang menjalani riyāạah rūhaniy, namun ia menjadikan tasawuf sebagai media untuk mendekatkan diri kepada Allah Swt. yang ajarannya kemudian ia kontekstualisasikan dengan kondisi umat saat ini. Hamka mendasarkan konsep tasawufnya ini pada kerangka agama dibawah pondasi Aqidah yang bersih dari praktik-praktik kesyirikan, dan amalan-amalan lain yang bertentangan dengan syari'at. Karena menurut Hamka berpendapat bahwa memungsikan tasawuf yang bersemangat juang perlu diartikulasikan secara modern. ${ }^{65}$

Hamka mendalami ilmu tasawuf secara otodidak. Hasil dari pendalamannya dalam bidang tersebut dengan menghasilkan buku yang berjudul "Tasawuf Modern". Martin Van Bruinessen and Julia Day Howell dalam "Sufisme and Modern In the Islam" mengatakan bahwa Hamka dalam bukunya tersebut berhasil mengajak muslim modern untuk menghargai esensi-esensi Tasawuf yang bernilai positif serta dapat dipelajari oleh umat Islam secara umum serta tidak memerlukan latihan dalam waktu yang lama di bawah bimbingan seorang Murshid. ${ }^{66}$

Peter Riddel dalam "Islam and The Malay - Indonesian World" menilai bahwa Hamka berhasil menempatkan ajaran Tasawuf pada tempat yang seadil-adilnya. Ini dibuktikan dengan dua karyanya di bidang Tasawuf, yaitu "Tasawuf Modern" dan "Tasawuf: Perkembangan dan Pemurniannya". Berdasarkan kedua karyanya itu, maka sudah jelas bahwa kecenderungannya pada Tasawuf mewarnai karya-karya yang dihasilkannya dalam kajian keislaman. ${ }^{67}$

Tak terkecuali, karyanya yang paling besar Tafsir al-Azhar pun tak lepas dari kecenderungannya tehadap Tasawuf. Hal ini dapat terlihat ketika ia mengkonsepsikan Mahabbah sebagai cinta Tuhan yang dibalas oleh Hamba-Nya. Cinta ini semakin bersemayam dengan adanya keterpautan pikiran kepada-Nya. Orang yang sudah mencapai derajat Maḥabbah akan memiliki perasaan yang tidak samar-samar lagi. Hijab dengan-Nya sudah hilang. Rasa Mahabbah, akan menimbulkan perasaan diri-Nya senantiasa menatapnya. Cinta sejati kepada Tuhan telah diajarkan Musa, yang

65 Mohammad Damami, Tasawuf Positif dalam Pemikiran Hamka (Yogjakarta: Fajar Pustaka Baru, 2000),h.177-180.

${ }^{66}$ Lihat Martin Van Bruinessen and Julia Day Howell (ed), "Sufisme and Modern In the Islam" (London and New York: I.B. Tauris, 2007), h. 229.

${ }^{67}$ Peter Riddel, Islam and The Malay - Indonesian World(Singapore: Horizon Books, 2001), 218. 
berintisari pengorbanan. Sipatnya ialah jalal, kemuliaan. Nabi Isa, membawa lanjutan ajaran berdasar akan $H u b b /$ cinta. Sifatnya adalah Jamāll indah. Nabi Muhammad menyempurnakan penyerahan kepada-Nya. Sifatnya adalah Kamāl. Hamka menambahkan bahwa terdapat juga cinta yang palus, yaitu cinta yang tidak disertai dengan kepatuhan. Cinta yang tidak mengikuti bimbingan Nabi. Maka ini adalah maghḍūb. Cinta yang direkareka dan direncanakan sendiri maka ia żălim. ${ }^{68}$

\section{Simpulan}

Dari pembahasan di atas, tafsir sufistik merupakan corak penafsiran al-Qur'an yang tidak hanya terikat dengan makna tekstual saja, tetapi lebih cenderung mengungkap isyarat-isyarat makna alegoris ayat-ayat al-Qur'an melalui jalan takwil penafsirnya. Makna-makna alegoris tersebut diarahkan pada konsep dan pengalaman spiritual (ậwā̄) sufistik yang ditangkap penafsirnya. Tafsir sufistik memiliki sejarah yang panjang, dari mulai zaman Nabi Saw dan terus berkembang sampai sekarang.

Eksistensi tafsir kaum sufi menjadi fenomena tersendiri. Hal ini dapat terlihat dari berbagai macam tanggapan terhadapnya, baik yang pro maupun yang kontra. Bagi yang kontra menganggap bahwa para sufi tidak otoritatif dalam menafsirkan al-Qur'an, karena penafsiran mereka terlalu jauh dari makna zăhir ayat. Pendapat tesebut mendapatkan sanggahan dari kalangan yang pro terhadap penafsiran sufistik, mereka mengatakan bahwa penafsiran kaum sufi tetap mengacu pada makna zăhir yang mereka peroleh melalui proses ijtihadi yang panjang. Dari landasan makna zăhir inilah para sufi membangun metode pemaknaan al-Qur'an secara ishärí atau menangkap isyarat halus yang tersembunyi dibalik makna zahir ayat al-Qur'an.

\section{DAFTAR PUSTAKA}

Abī Shaybah, Abī Bakr 'Abdillāh bin Muhammad. al-Mușsannaf Li Ibn Abī Shaybah. Jeddah: Dār al-Qiblah, 2006.

Abū Zayd, Nașr Hāmid. Mafhūm al-Nash. Kairo: Matba'ah al-Ḥayāt alMisriyyah li 'Ammat al-Kitāb, 1993.

Amin, Bakri Syaikh. Al-Ta’bïr al-Fannī fì al-Qur'ān. Kairo: Dār al-Shurūq, 1980.

'Arabī, Ibn. Fușūṣ al-Hikam. Beirut: Dār al-Kitāb al-'Arabiy, t.th.

Bashūnī, Ibrāhìm. Nash'at al-Tașawwuf al-Islāmi. Kairo: Dār al-Ma'ārif bì al-Miṣr, t.th.

${ }^{68}$ Hamka, Tafsir al-Azhar (Jakarta: Citra Serumput, 1982), Juz III, 218. 
Bruinessen, Martin Van and Julia Day Howell (ed). Sufisme and Modern In the Islam. London and New York: I.B. Tauris, 2007.

Al-Bukhārì, Muhammad ibn Ismā'ìl. Sahīh al-Bukhārī. Kairo: Dār al-Ḥadith, 2004.

Damami, Mohammad. Tasawuf Positif dalam Pemikiran Hamka. Yogjakarta: Fajar Pustaka Baru, 2000.

Al-Dhahabi, Muhammad Husayn. Al-Tafsìr wa al-Mufassirūn. Kairo: Maktabah Wahbah, 2000.

Fawdah, Maḥmūd Basunī. al-Tafsìir wa Manāhijuhu. Kairo: Matba'ah alAmānah, 1977.

Goldziher, Ignaz. Mazhab Tafsir; Dari Klasik Hingga Modern. Yogyakarta: eLSAQ Press, 2010.

Hamka. Tafsir al-Azhar. Jakarta: Citra Serumput, 1982.

Hilāl, Ibrāhīm. Al-Tasạwwuf al-Islāmi baina al-Dīn wa al-Falsafah. Kairo: Dār al-Nahḍah al-'Arabiyah, 1979.

Keeler, Annabel. "Ṣüfî tafsīr as Mirror: al-Qushayri the Murshid in his Lațā'if al-Ishāarāt." Journal of Qur'anic Studies Vol. 8, No. 1 (2006) http://www.jstor.org/stable/25728196. (diakses 22 Maret, 2014).

Khaldun, Ibn. Muqaddimah Ibn Khaldun. Beirut: Dār al-Qalām, 1981. Mahyuddi. Kuliah Akhlak Tasawuf. Jakarta: Kalam Mulia, 2003.

Manzūur, Ibn. Lisān al- 'Arab. Kairo: Dār al-Ma'ārif, t.t.

Mojaddedi, Jawid A. "Legitimizing Sufism in al-Qushayri's Risala." Studia Islamica, No. 90 (2000) http://www.jstor.org/stable/1596163. (diakses 4 Maret, 2014).

Mustaqim, Abdul. Epistemologi Tafsir Kontemporer. Yogyakarta: LKIS, 2012.

Nata, Abuddin. Metodologi Studi Islam. Jakarta: Rajawali Pers, 2012.

Nasution, Harun. Falsafat dan Mistisme dalam Islam. Jakarta: Bulan Bintang, 1992. 1995. . Islam Rasional; Gagasan dan Pemikiran. Bandung: Mizan,

Noer, Kautsar Azhari. Ibn Al-'Arabì; Waḥdat al-Wujūd dalam Perdebatan. Jakarta: Paramadina, 1995.

Al-Qatțān, Mannā'. Mabāhith fì 'Ulūm al-Qur'ān. Kairo: Maktabah Wahbah, 2000.

Al-Qadir, Jum'ah 'Alì 'Abd. Zād al-Rāghibīn fí Manāhij al-Mufassirīn. Kairo: Kuliyah Ușūl al-Dīn Jāmi’ah al-Azhar, 1986.

Riddel, Peter. Islam and The Malay - Indonesian World. Singapore: Horizon Books, 2001. 
Sands, Kristin Zahra. Süfí Commentaries on The Qur'ān in Classical Islam. New York: Routledge, 2006.

Shihab, Muhammad Quraish. Membumikan al-Qur'an: Fungsi dan Peran Wahyu dalam Masyarakat. Bandung: Mizan, 1994.

Siregar, Rivay. Tasawuf; Dari Sufisme Klasik ke Neo-Sufisme. Jakarta: Raja Grafindo Persada, 2002.

Al-Ṣuyūțì, Jalāl al-Dīn. Al-Itqān fì 'Ulūm al-Qur'ān. Kairo: Maktabah wa Maṭba'ah al-Mashhad al-Husyni, 1967.

Syarifuddin, M. Anwar. "Menimbang Otoritas Sufi dalam Menafsirkan AlQur'an." Jurnal Studi Agama dan Masyarakat, Vol. 1, no. 2 (2004). . "Hermenetika Sufi Sahl Ibnu Abdullah AlTustari" dalam Kusmana dan Syamsuri (eds), Pengantar Kajian AlQur'an: Tema Pokok, Sejarah dan Wacana Kajian. Jakarta: PT Pustaka Al-Husna Baru, 2004.

Syukur, M. Amin. Menggugat Tasawuf; Sufisme dan Tanggung Jawab Abad 21. Yogyakarta: Pustaja Pelajar, 2002.

Al-Ṭusisi, Al-Sirāj. al-Lumā'. Kairo: Dār al-Kutūb al-Ḥadithah, 1960. 